\title{
THE IMPACT OF LOCAL AUTHORITIES INTERVENTIONS ON HOUSEHOLD WASTE COLLECTION: A CASE STUDY APPROACH USING TIME SERIES MODELLING
}

\section{Full reference:}

Cole, C., Quddus, M., Wheatley, A., Osmani, M., (2014). The impact of Local Authorities' interventions on household waste collection: a case study approach using time series modelling. Waste Management, 34 (2) 266-272.

\begin{abstract}
:
At a local Government level there have been many interventions and changes made to household waste collection services to meet new regulatory requirements. These changes include separate collection of recyclable and organic materials. This paper has used a time series model to quantify the success of interventions introduced by a LA.

The case study was a medium sized UK LA, Charnwood Borough Council (CBC), the research analyses monthly data of quantities of recyclates, garden waste for composting and residual waste for landfill disposal. The time series model was validated with a five year data set and used to measure the impacts of the various changes to identify which intervention was the most successful, while controlling for season and number of working days. The results show the interventions analysed both had abrupt and permanent positive impacts on the yield of recyclable materials, and a corresponding negative impact on the residual waste.

The model could be added to the National data base to help LAs to compare interventions and to understand which schemes encourage householder participation and improve recycling performance.
\end{abstract}

Keywords: intervention; time series analysis; recycling; household waste

Paper type: Published peer reviewed journal 


\section{Introduction}

Concerns about volumes of waste generated, long term resource depletion and the environmental impact of waste has led to legislation and fiscal measures to control waste. Local Authorities (LAs) have had to rethink household waste management to focus more on prevention, reuse and recycling. The revised Waste Framework Directive, 2008 aimed to ensure reuse and recycling reached levels of at least $50 \%$ of waste materials (paper, metal, plastic, glass and biodegradable waste) from households by 2020. In the UK Local Authorities (LA) have the responsibility for household waste management and the policies for reuse and recycling.

The case study is from Charnwood Borough Council (CBC), a Waste Collection Authority in the East Midlands of England. This paper uses a time-series model to assess the impact of interventions made by the LA in its efforts to recycle more. These interventions include simplifying sorting and separation requirements for collection and recovering new materials.

\section{Recycling Household Waste}

The Waste Strategy for England, 2007 increased existing targets for English LAs to recycle and compost household waste. These targets and the increasing cost of landfill disposal due to the escalating Landfill Tax encouraged LAs to collect materials for recycling and bio-treatment separately from households.

Separate kerbside collections of common, heavy, easily recyclable materials (glass, metals, cardboard and paper) enabled UK LAs to achieve 43\% recycling in 2011/12 (Defra, 2012). Annual amounts recycled since 2001/02 increased from 3.2 to 10.7 million tonnes in 2011/12. The additional separate collection of organic waste, garden and/or food waste by some LAs has achieved reductions in household waste disposal up to 69\% (Defra, 2012).

The devolved governments of Wales, Scotland and Northern Ireland have different strategies with progressively higher targets (Table 1) than the UK as a whole (which is to reuse, or recycle $50 \%$ of household waste by 2020 , to meet the EU revised Waste Framework Directive.

Table 1: Recycling targets set by the individual UK governments. Source - Waste Strategy for England, 2007; Scotland, Zero Waste Plan (2010); Wales, Towards Zero Waste (2010); Northern Ireland - Towards Resource Management: The Northern Ireland Waste Management Strategy 2006 - 2020 (2006)

\begin{tabular}{lcccclc}
\hline & $\mathbf{2 0 1 0}$ & $\mathbf{2 0 1 3}$ & $\mathbf{2 0 1 5}$ & $\mathbf{2 0 1 6}$ & $\mathbf{2 0 2 0}$ & $\mathbf{2 0 2 5}$ \\
\hline England & $40 \%$ & & $45 \%$ & & $50 \%$ & $70 \%$ \\
\hline Scotland & $40 \%$ & $50 \%$ & & & $60 \%$ & $70 \%$ \\
\hline Wales & $40 \%$ & $52 \%$ & & $58 \%$ & $64 \%$ & $\begin{array}{l}45 \% \text { (with plans to } \\
\text { increase to 60\%) }\end{array}$ \\
\hline N Ireland & $35 \%$ & & $40 \%$ & & \\
\hline
\end{tabular}

Jenkins et al. (2003) found LAs that provided households with a kerbside collection rather than relying on householders to take recyclable materials to a specified collection point achieved twice as much recycling (by weight). It is now agreed source separation is critical to meet the target of 50\% recycling of household waste by 2020 (Barr and Gilg, 2005; Dahlen and Lagerkvist, 2010). The majority of UK LAs operate separate collections of recyclates and 
residual waste (WRAP, 2009). However, this increases the complexity of waste collection from one container to several collections of multiple materials; often working to different timescales (i.e. alternate weeks). The success of these separations is increasingly dependent on cooperation from householders (Watson and Bulkeley, 2010). It is generally easy to obtain the involvement of the aware and informed but even in the best performing areas about $20 \%$ of households do not use the recycling collection service (Harder and Woodward, 2007). This paper reports on a technique for analyzing the success of various interventions.

One generally reported factor is collection complexity, simpler and more convenient collection systems get better householder participation (Woodward et al., 2005; Read, 1999; Barr and Gilg, 2005). For example, Barr and Gilg (2005) found that householders were confused when asked to separate materials into different containers and consequently produced more residual waste. Similarly, Oom do Valle (2009) argued that collection services with many different containers had lower participation rates. Martin et al. (2008) reported collection schemes limited to two containers, one for recyclates and one for waste, were more popular with residents than those with multiple containers.

Research into householders' participation found collection services designed to suit property types produced higher levels of recycling (Wilson and Williams, 2007). For example, available space might preclude large multiple containers for some households (Tucker et al., 2001; Barr and Gilg, 2005), therefore, the use of smaller containers (bags or boxes) for those with limited storage space increased participation in apartments blocks (Barr and Gilg, 2005; den Boer et al., 2007).

Previous work noted an influence from frequency of collections, LAs reducing collections of residual waste to fortnightly from weekly achieved more recycling (WRAP, 2009). This study suggested that the reduced collection frequency forced householders to manage their waste by recycling. The 10 LAs in England with the highest recycling rates used fortnightly rather than weekly collections and achieved 30\% more separation (LGA, 2007). This was corroborated in data from McLeod and Cherrett (2007) who measured a $20 \%$ shift from residual waste into recycling following a change to fortnightly collections with separated garden waste.

Availability of centralised separation, treatment methods and appropriate vehicles, influences the type of householder separation used (ICE, 2011; Eriksson et al., 2005). Therefore, there are a variety of LA waste collection systems in use, which vary according to housing types (Muhle et al., 2010), population density (Emery et al., 2007), and available waste infrastructure.

LAs have a statutory duty to collect and keep records of waste collected from households (Environmental Protection Act, 1990). This data records the weight of waste, its origin and ultimate disposal or treatment routes. Waste quantities are measured using weighbridge figures (waste transfer notes), providing an auditable mass balance. Quantities recycled or treated are compiled by type and as a percentage of the household waste collected. Information is reported quarterly to the Department for Environment, Food \& Rural Affairs (Defra), the UK Government Department responsible for waste treatment, via a web based spread sheet (WasteDataFlow), enabling Defra to compare trends in recycling, disposal and treatment between LAs.

\section{Previous time series modelling of household waste}


The requirement to provide monthly returns for WasteDataFlow has provided an archive of data from April 2005, and the time series analysis model (Box and Tiao, 1975) could provide a guide to the success of increasing the simplicity of sorting compared to dissemination campaigns on the amounts recycled.

Beigel et al. (2008) provides a review of models used for predictions of waste generation. These include planning of waste collection services, waste treatment facilities and the development of waste management strategies. The study concluded that there were many differences in the way time series models had been used and there were also differences in the way the original data was collected. Sample sizes for example, varied from household to city level and this meant that the independent variables used in models also differed greatly. The alternative definitions used for waste streams and waste streams complicated the comparison of results.

Previous use of time series or statistical analysis with data to forecast future amounts of waste to aid planning includes Matsuto and Tanaka (1993) who used a moving average of daily waste collected in a Japanese city to understand the impact of seasons and holidays and collecting waste on different days of the week. Chang and Lin (1997) also used monthly time series data, from a similar sized community to this study, alongside social and demographic information to predict future waste Results were used to aid the decision between building incinerators or more complex infrastructure for recycling and recovery.

Hsu and Kuo (2005) were able to use multiplicative ARIMA (Autoregressive Integrated Moving Average) model to predict changes in the amounts and categories of household waste generated and their rates of recycling. From this analysis they were able to predict the impact of separate collection of the increasing amounts of household electrical and electronic appliances in Taiwan.

\section{Methods}

\subsection{Charnwood Borough Council (CBC) case study}

To meet the regulations, CBC has, in common with most other LAs, introduced a door-to-door kerbside collection of recyclables. It has also carried out campaigns to raise public awareness and encourage the use of these schemes. There has been little published on how effective these changes to LA collection practices have been in achieving waste reductions. Waste collections in CBC area cover 67,000 households and in 2010/11 46.1\% was recycled and composted. This paper uses time series analysis to measure the performance of three different types of intervention. This analysis was then used to forecast the trends in household waste and how to achieve the EU targets.

The three $\mathrm{CBC}$ intervention events examined in this research are:

- August 2007, collection of mixed plastics and Tetrapak (drinks) containers were added to the existing segregated collections of paper, cardboard, glass and metals. As these are lightweight, was unknown how useful their inclusion would be on the recycling target.

- August 2009, the number of containers used for the separate collection of recyclates was reduced from four to three (including garden waste). Dry recyclates were now separated into just two containers, one for glass; and one for all plastics, metals, paper and cardboard. The literature suggested that simplification would help avoid 
confusion for householders about which container, if any, to sort their waste types into. An increase in householders' participation was anticipated.

- During September 2011, the household waste collection was simplified further to three wheeled bins. One was for all dry recyclable materials, this included paper, cardboard, glass, metals and mixed plastic items. The two other wheeled bins were for the separate collection of organic (garden) waste and the remaining residual waste for disposal. This was a further simplification to compare with the August 2009 change.

The movement of recyclable materials from the residual landfill waste stream into the recycling stream was also monitored to confirm the correlation with a reduction in the amount of landfill disposal.

\subsection{Archived CBC household waste data}

Archived data of the monthly local waste records kept by $\mathrm{CBC}$ for reporting to the UK Government Department, Defra (Department for Environment, Food \& Rural Affairs) is divided into three categories:

- materials collected for reuse and recycling;

- garden waste (organics) for composting; and

- residual waste (all other waste) for landfill disposal.

The data set covered seven years (April 2005 to March 2012) to include a period prior to and then the three interventions in 2007, 2009 and 2011. A mass balance was possible of materials passing the three streams to corroborate shifts from the residual landfill waste stream into the recycling stream.

Administrative records together with internal reports and public records were also used to compile a history of changes to practice in case there were other changes to confound the data. Figure 1 shows a time series plot of monthly data of waste collected for recycling, that exhibits both trend and seasonality. 


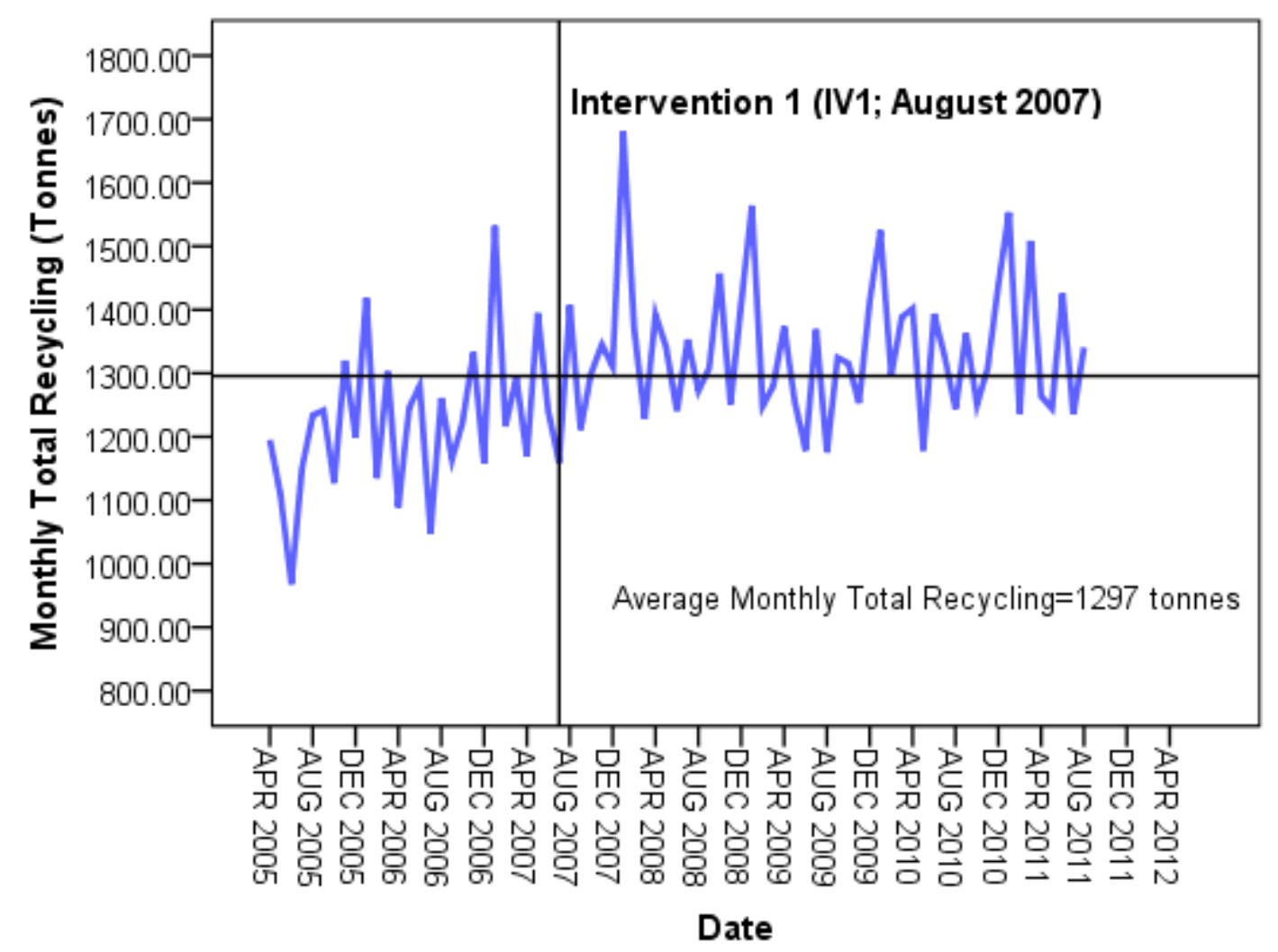

Figure 1: A sequence chart of monthly total recycling (April 2005 to March 2012) 


\section{Time series model}

The changes in the materials collected and methods of collection are shown in Table 2.

Table 2: Amendments made to the household waste and recycling collections in Charnwood Borough Council. (Authors research using Charnwood Borough Council archived Council Committee Papers, 2004- 2009).

\begin{tabular}{|c|c|c|c|}
\hline Year & Materials collected & Containers & Amendment to waste service \\
\hline \multirow[t]{2}{*}{2004} & $\begin{array}{l}\text { Paper } \\
\text { Steel \& aluminium food \& } \\
\text { drink cans }\end{array}$ & $\begin{array}{l}\text { Red bags } \\
\text { Green bags }\end{array}$ & $\begin{array}{l}\text { Introduction of kerbside } \\
\text { recycling collections }\end{array}$ \\
\hline & Residual waste for landfill & Black bags & $\begin{array}{l}\text { Weekly collection of residual } \\
\text { waste }\end{array}$ \\
\hline \multirow{5}{*}{$\begin{array}{l}2005 \\
(\mathrm{Feb})\end{array}$} & \multirow{5}{*}{$\begin{array}{l}\text { Paper \& cardboard } \\
\text { Steel \& aluminium food \& } \\
\text { drink cans } \\
\text { Glass } \\
\text { Residual waste to landfill }\end{array}$} & Red bags & \multirow{5}{*}{$\begin{array}{l}\text { Cardboard added to } \\
\text { collections } \\
\text { Separate container issued for } \\
\text { collection of glass } \\
\text { Introduction of black wheeled } \\
\text { bins for household waste } \\
\text { Collection frequency changed } \\
\text { from weekly to fortnightly }\end{array}$} \\
\hline & & Green bags & \\
\hline & & & \\
\hline & & Black wheeled bins & \\
\hline & & & \\
\hline 2005 & Garden waste & $\begin{array}{l}\text { Brown wheeled } \\
\text { bins }\end{array}$ & $\begin{array}{l}\text { Introduction of fortnightly } \\
\text { garden waste collection - opt } \\
\text { in service with an annual } \\
\text { charge to householders }\end{array}$ \\
\hline \multirow{4}{*}{$\begin{array}{l}2007 \\
\text { (Aug) }\end{array}$} & Paper \& cardboard & Red bags & \multirow{4}{*}{$\begin{array}{l}\text { Addition of mixed plastics and } \\
\text { tetra-paks to the recyclable } \\
\text { materials collected }\end{array}$} \\
\hline & $\begin{array}{l}\text { Steel \& aluminium food \& } \\
\text { drink cans }\end{array}$ & Green bags & \\
\hline & Glass & 55 litre box & \\
\hline & Residual waste to landfill & Black wheel & \\
\hline \multirow{5}{*}{$\begin{array}{l}2009 \\
(\text { Aug) }\end{array}$} & $\begin{array}{l}\text { Paper, cardboard, steel \& } \\
\text { aluminium cans \& mixed } \\
\text { plastic }\end{array}$ & Purple bags & \multirow{5}{*}{$\begin{array}{l}\text { Simplifying collection scheme } \\
- \text { reduction in number of } \\
\text { containers issued to } \\
\text { householders, less sorting for } \\
\text { the householder }\end{array}$} \\
\hline & Glass recycling & 55 litre box & \\
\hline & Garden waste & Brown wheeled & \\
\hline & Residual household waste & bins & \\
\hline & & Black wheeled bins & \\
\hline \multirow{4}{*}{$\begin{array}{l}2011 \\
(\text { Sept })\end{array}$} & $\begin{array}{l}\text { Paper, cardboard, steel \& } \\
\text { aluminium cans \& mixed } \\
\text { plastic }\end{array}$ & Green wheeled bin & $\begin{array}{l}\text { All collections fortnightly } \\
\text { Recyclates collected in one } \\
\text { container }\end{array}$ \\
\hline & Garden waste & Brown wheeled bin & \multirow{3}{*}{$\begin{array}{l}\text { Opt in service with an annual } \\
\text { charge to householders- } \\
\text { Fortnightly collection } \\
\text { Fortnightly collection }\end{array}$} \\
\hline & Residual waste & Black wheeled bin & \\
\hline & & & \\
\hline
\end{tabular}

Data was analysed using an ARIMA (Autoregressive Integrated Moving Average) time series model as suggested by Hsu and Kuo (2005). Analysis of the three waste streams used the following model: 


$$
y_{t}=f(I, X)+N_{t}
$$

- $t$ is the discrete time (e.g. month in this case),

- $y_{t}$ is the appropriate Box-Cox transformation of $y_{t}$, say in $y_{t}, y_{t}^{2}$, or $y_{t}$ itself (e.g. Box and Cox, 1964), $y_{t}$ is the dependent variable for a particular time $t$ representing the total monthly household waste, or garden waste or waste for recycling,

- $f(I, X)$ is the dynamic part of the model which contains the intervention component $(I)$ and the deterministic effects of independent control variables $(X)$, and

- $N_{t}$ is the stochastic variation or noise component.

Noise and intervention components, control variables and cross correlation between data are briefly discussed below for completeness.

\subsection{Intervention function $\mathbf{f}(\mathrm{I})$ :}

Intervention functions are used to examine the impact of an identified change in time series data (Box and Tiao, 1975; Jorquera et al., 2000). In this research, these are amendments to collection methods and range of recycled materials shown in Table 2. Interventions may produce both the onset (i.e. abrupt or gradual) and duration (permanent or temporary) effects meaning that there are four possible combination effects. The connection between an intervention and its likely effects is termed as a transfer function. For instance, an impulse transfer function is likely to occur once with abrupt onset and temporary duration. On the other hand, a step transfer function is likely to produce an effect with abrupt onset and permanent or long duration (i.e. an immediate impact and continue over the long term). It was envisaged that the interventions were likely to be step functions and this was used to define the changes as follows:

$$
f\left(I_{t}\right)=\varpi_{0} I_{t}
$$

where $\varpi_{0}$ is a constant, and $I_{t}$ is the intervention variable which takes a value of 0 for every month before the implementation date of the amendment and a value of 1 for every month thereafter, i.e.,

$$
I_{t}=\left\{\begin{array}{lc}
1 & \text { for } t \geq t^{\prime} \\
0 & \text { elsewhere }
\end{array}\right.
$$

Then equation (3) becomes

$$
f\left(I_{t}\right)=\left\{\begin{array}{cc}
0 & \text { for } t<t^{\prime} \\
\varpi_{0} & \text { for } t \geq t^{\prime}
\end{array}\right.
$$


and the general intervention model takes the following form:

$$
y_{t}=\varpi_{0} I_{t}+\boldsymbol{\beta} \boldsymbol{X}+\frac{\theta(B) \Theta(B) u_{t}}{\phi(B) \Phi\left(B^{s}\right)(1-B)^{d}\left(1-B^{s}\right)^{D}}
$$

Intervention analysis starts with the identification of a SARIMA model (i.e. noise component) parameters $p, d, q, P, D$, and $Q$ using the autocorrelation function (ACF) and the partial autocorrelation function (PACF) of a series, their estimation and diagnosis of the observations before intervention. The next step is to re-estimate the model for the entire series by including intervention variables (usually dummy variables) that represent the timing of the intervention. Some other independent variables (usually control variables) can also be added in the reestimation step. The statistical significance of the intervention variables, in our case $\varpi_{0}$, explains whether the intervention has any effect on the time series and the magnitude of their coefficients measures the substantive effect of the intervention.

\subsection{Control variables}

There are three main components to the models: the intervention variables, the seasonal ARIMA parameters, and a control variable - number of working days per month. Waste collection services in CBC are operated following a four day working week between Tuesday and Friday. The number of working days during each month was also calculated. These were included to take account of the availability of collection services.

\subsection{Cross-correlation among the series}

It was assumed, because of the mass balance, that materials recycled would be lost from the residual waste stream. It could, therefore, be hypothesized that the recycling data will lead the residual waste data. This can be examined by the cross-correlation of the white noises from these two series (Box et al., 1976). Cross-correlation can reveal the inter-relationships between the series, their significance and the lead/lag in any correlation.

If $\boldsymbol{u}_{\boldsymbol{t}}, \boldsymbol{v}_{\boldsymbol{t}}$ denote the white noises (i.e. residuals) from the waste for recycling and residual waste series, the cross-correlation coefficient at lag $k$ between these white noises can be expressed as (Box et al., 1976):

(6)

$$
r_{u v}(k)=\frac{C_{u v w}(k)}{S_{u} S_{v}}
$$

$C_{u v w}(k)$ is the correlation at lag $\mathrm{k}$ and $S_{u}$ and $S_{v}$ are the standard deviations of the white noises.

\subsection{Noise component $(\mathrm{Nt})$ :}


If a purely random component $\left(N_{t}\right)$ is present it follows either a standard Autoregressive Integrated Moving Average (ARIMA) model, denoted as ARIMA $(p, d, q)$ or a Seasonal Autoregressive Integrated Moving Average (SARIMA) model (e.g. Box and Tiao, 1975), denoted as SARIMA $(p, d, q) \times(P, D, Q)_{S}$; if there are seasonal effects on the sequence of observations). In both models, $p$ is the order of the non-seasonal autoregressive (AR) process; $P$ is the order of the seasonal AR process; $d$ is the order of the non-seasonal difference; $D$ is the order of the seasonal difference; $q$ is the order of the non-seasonal moving average (MA) process; $Q$ is the order of the seasonal MA process; the subscript $s$ is the length of seasonality (for example $s=12$ with monthly time series data). The SARIMA $(p, d, q) \times(P, D, Q)_{S}$ model can be expressed as (see Box et al., 1994):

$$
\phi(B) \Phi\left(B^{s}\right)(1-B)^{d}\left(1-B^{s}\right)^{D} N_{t}=\theta(B) \Theta(B) u_{t}
$$

where

- $\phi$ and $\Phi$ are the regular and seasonal AR operators,

- $\theta$ and $\Theta$ are the regular and seasonal MA operators,

- $\quad B$ and $B^{s}$ are the backward shift operators, and

- $u_{t}$ is an uncorrelated random error term with zero mean and constant variance $\left(\sigma^{2}\right)$.

\section{Results}

\subsection{Results from the intervention models}

Changes in monthly recycling waste, garden waste, and residual waste were measured in the model to compare the impact of the three interventions noted at 4.1.

At the time of writing monthly waste flow data for CBC was available until March 2012; and analysis of the third intervention is unreliable due to lack of sufficient observations (i.e. only seven observations are available). Therefore, results are based on the first two interventions.

Table 3 shows results and relevant statistics of three intervention models, disaggregated by waste category. The autocorrelation function (ACF) and partial autocorrelation function (PACF) of the series and the residuals and the modified Box-Pierce (Ljung-Box) Q statistic are used to identify the model parameters. It is noticeable that the patterns among these series are quite different as total recycling follows a SARIMA $(0,0,0) \mathrm{x}(1,0,0)$ model containing only a first order seasonal AR(1) term, the garden waste follows a SARIMA $(0,0,0) \times(1,1,0)$ containing only a first order seasonal AR(1) term but the residual waste follows a SARIMA $(2,0,0) \times(2,0,0)$ model with two non-seasonal AR terms and two seasonal AR terms. In the case for the garden waste -it was essential to carry out one seasonal $(D=1)$ difference to obtain a stationary time series. However, none of the series contains any $q$ terms in the patterns suggesting that there are no lingering effects of preceding random shocks in any of the studied series. The results show that residuals from all series exhibit white noise which confirms that the developed intervention models are reliable. 
Table 3: Results from the time-series intervention models

\begin{tabular}{|c|c|c|c|c|c|c|}
\hline \multirow{3}{*}{\begin{tabular}{|l} 
Intervention Models \\
Noise Components \\
\end{tabular}} & \multirow{2}{*}{\multicolumn{2}{|c|}{$\begin{array}{l}\text { Total Recycling } \\
\text { SARIMA } \\
(\mathbf{0 , 0 , 0 )} \times(\mathbf{1 , 0 , 0 )} \\
\end{array}$}} & \multirow{2}{*}{\multicolumn{2}{|c|}{$\begin{array}{l}\text { Garden Waste } \\
\text { SARIMA } \\
(\mathbf{0 , 0 , 0 ) \times ( 1 , 1 , 0 )} \\
\end{array}$}} & \multirow{2}{*}{\multicolumn{2}{|c|}{$\begin{array}{l}\text { Residual waste } \\
\text { SARIMA } \\
(2,0,0) \times(2,0,0) \\
\end{array}$}} \\
\hline & & & & & & \\
\hline & Coefficient & t-stat & Coefficient & t-stat & Coefficient & t-stat \\
\hline Constant & & & 92.49 & 8.73 & 583.16 & 3.94 \\
\hline Autoregressive, AR(1) & & & & & 0.047 & 3.98 \\
\hline Autoregressive, AR(2) & & & & & 0.30 & 2.64 \\
\hline $\begin{array}{l}\text { Seasonal Autoregressive, } \\
\text { SAR(1) }\end{array}$ & 0.73 & 8.56 & -0.59 & -3.87 & 0.23 & 2.35 \\
\hline $\begin{array}{l}\text { Seasonal Autoregressive, } \\
\text { SAR(2) }\end{array}$ & & & & & 0.43 & 3.87 \\
\hline \multicolumn{7}{|l|}{ Control Parameter } \\
\hline Number of working day & 70.67 & 48.53 & & & 121.62 & 14.50 \\
\hline \multicolumn{7}{|l|}{ Intervention } \\
\hline $\begin{array}{l}\text { Amendments made in Aug } \\
2007 \text { (increasing household } \\
\text { waste recyclable material } \\
\text { streams) }\end{array}$ & 90.58 & 4.22 & & & -119.97 & -3.71 \\
\hline $\begin{array}{l}\text { Amendments made in Aug } \\
2009 \text { (simplification of } \\
\text { household waste collection) }\end{array}$ & 110.71 & 4.03 & & & -176.24 & -4.16 \\
\hline \multicolumn{7}{|l|}{ Descriptive statistics } \\
\hline Series Length & 77.00 & & 77.00 & & 0.77 & \\
\hline Pseudo R-squared & 0.61 & & 0.82 & & 0.76 & \\
\hline $\begin{array}{l}\begin{array}{l}\text { Ljung-Box } \\
\text { value) }\end{array} \\
\end{array}$ & $10.37(0.89)$ & & $14.96(0.59)$ & & $12.43(0.57)$ & \\
\hline
\end{tabular}

The - number of working days per month - (control variable) was found to be statistically significant with a positive coefficient in the waste for recycling and residual waste models and not significant in the garden waste model. This may be due to the strong seasonal effect on this waste stream and this waste stream is a standalone collection, with no impact on the other waste streams. The model indicates that one additional working day per month would increase waste for recycling by about 70 tonnes per month and residual waste by 121 tonnes per month.

Both intervention variables when assumed to follow a step function were found to be statistically significant in the waste for recycling and residual waste models but were not significant in the garden waste model.

The amendments made both brought about an abrupt and permanent positive impact on the waste collected for recycling, which increased by about 91 tonnes per month from the first intervention (Aug 2007) and 111 tonnes per month from intervention 2 (Aug 2009, Table 2).

Both interventions were found to have a significant and negative impact on the residual waste; reducing the amount collected by 120 tonnes per month after the implementation of the first intervention, with a larger reduction (i.e. 176 tonnes) after the implementation of second intervention.

The amendments were statistically insignificant in the garden waste model because no changes were made to the way garden waste was collected. These collections continued as before following the same fortnightly collection frequency and same four day working week pattern. 


\subsection{Cross-correlation between residual waste and total recylcing}

The cross-correlation function as denoted by equation (6) between the white noises of the waste for recycling and residual waste series was used to support the assumption that an increasing in recycling would lead to a corresponding decrease in residual waste for landfill.

The cross-correlation coefficient values up to lag 24 are plotted and shown in Figure 2.

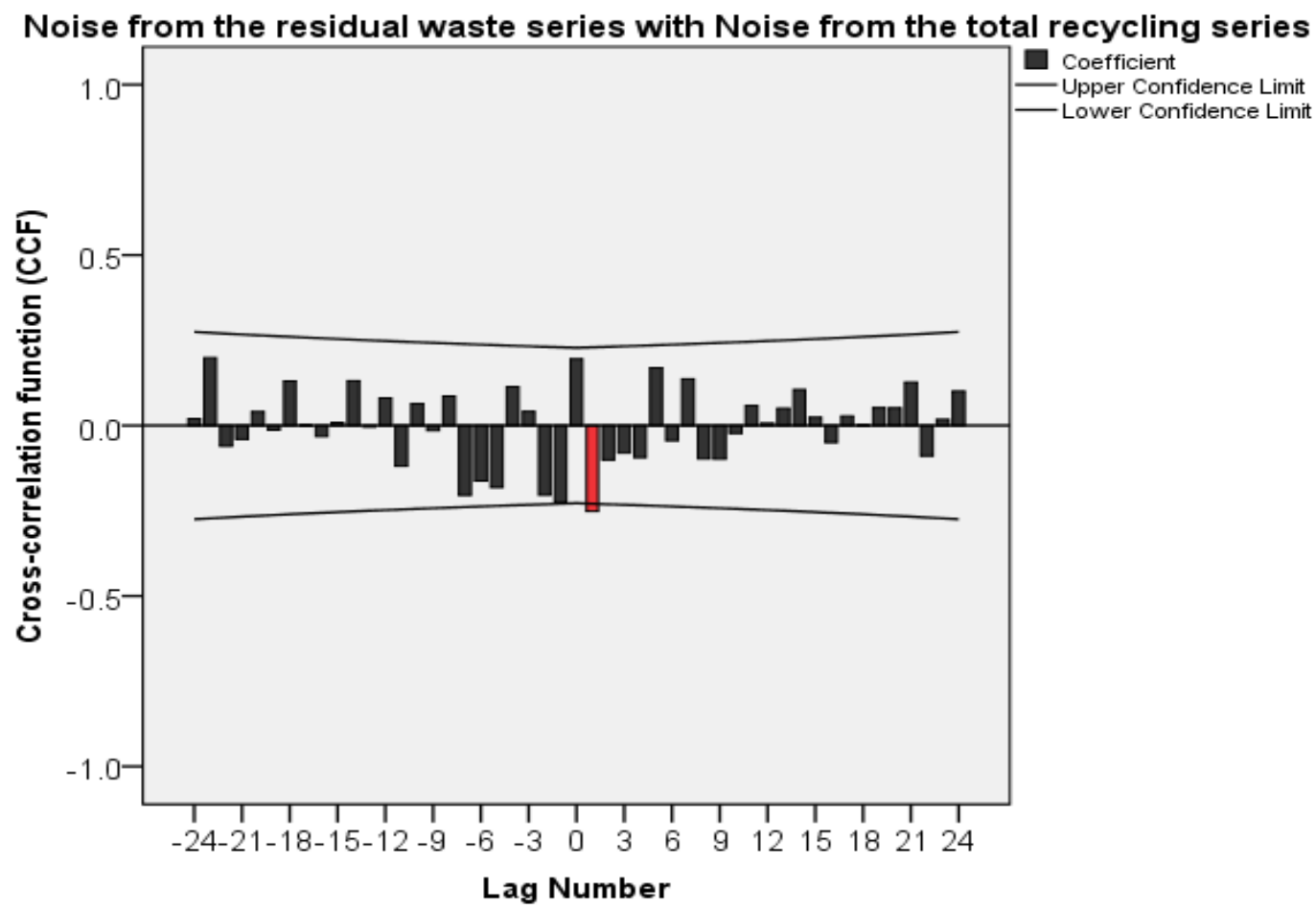

Figure 2: Cross-correlation function between noise residuals from the residual waste and total recycling models

Figure 2 shows the correlations are small with both positive and nagative lags. A negative lag suggests that the first series (i.e. monthly residual waste) follows the second series (i.e. the monthly waste for recycling). The value of the cross-correlation coefficient is negative at a positive lag 1 (i.e. -0.252) suggesting that an increase in the values of the leading series (i.e. recycling) will cause a decrease at the values of the second series (i.e. residual waste) one month later.

\subsection{Model performance}

The performance of the models was estimated using Mean Absolute Error (MAE) as shown below:

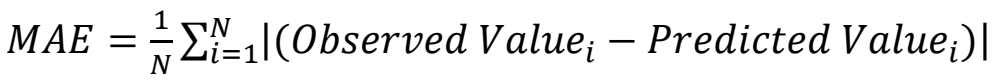

Data was divided into two groups (1) sample observations (April 2005 to August 2011) that were employed in estimating the models and (2) the smaller number of sample observations not used in modelling (September 2011 to March 2012). MAE in predicting monthly recycling/residual wastes was then calculated for both cases (see Table 4). The results show that the model is better at predicting waste for recycling than residual/garden wastes. 
Table 4: Mean Absolute Error from the models

\begin{tabular}{lrcc}
\hline & & \multicolumn{2}{c}{ Mean Absolute Error (MAE) } \\
\hline & $\begin{array}{c}\text { Pseudo } \\
\text { squared }\end{array}$ & $\begin{array}{c}\text { Within } \\
\text { sample }\end{array}$ & Out of sample \\
\hline Total recycling & 0.61 & 60.98 & 108.9 \\
\hline Garden waste & 0.82 & 131.79 & 159.0 \\
\hline Residual waste & 0.76 & 101.02 & 118.9 \\
\hline
\end{tabular}

The pattern of prediction is compared with actual recycled amounts in Figure 3.

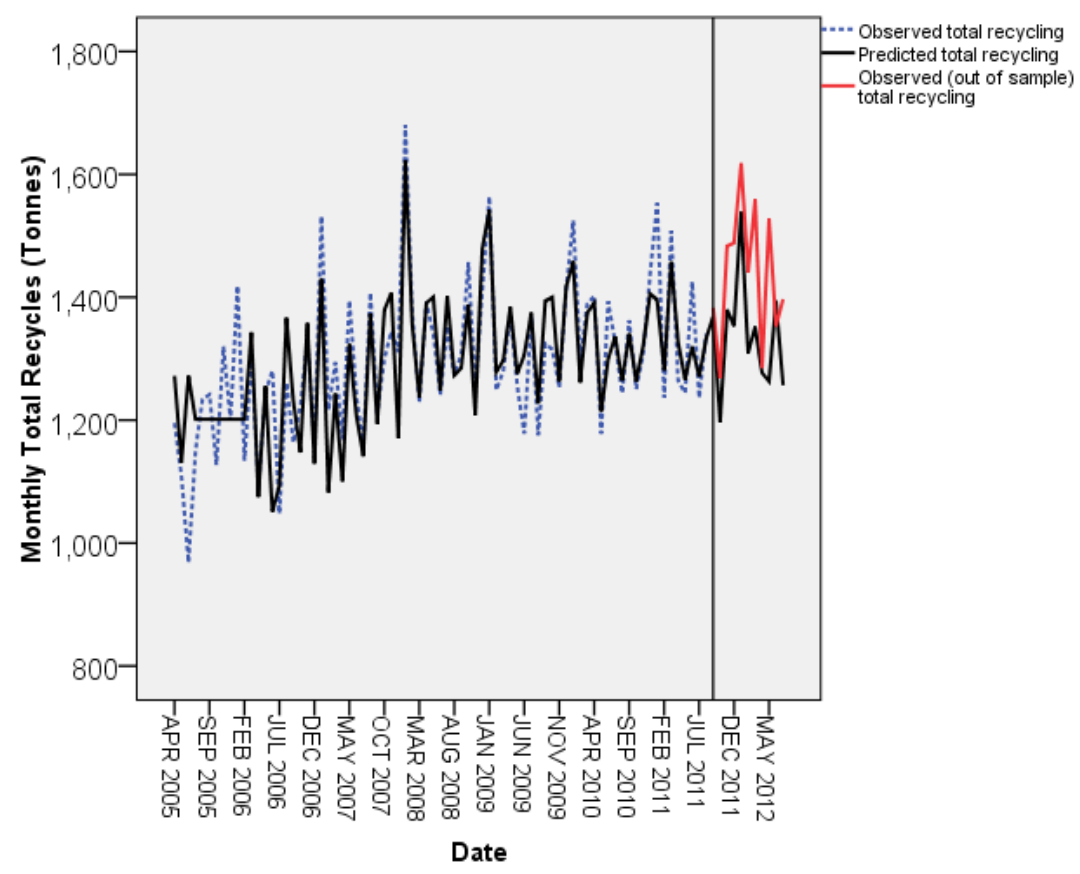

Figure 3: Comparison of observed and predicted data

The performance of the model deteriorates after July 2011, when the third intervention took place. This suggests that further validation of the model after this change would be necessary to refine its ability to predict seasonal changes.

\section{Discussion}

The time series model shows the long term upwards trend in recycling by households within $\mathrm{CBC}$, which follows the national pattern. The interventions taken by CBC were shown to cause step and permanent improvements to the amounts of recyclate recovered from households. The second, simpler separation better than the first (more materials). Nevertheless the results have demonstrated the importance of having facilities to extend the range of materials collected.

Previous studies show existing household recyclers are most likely to support new recycling schemes (Burnley and Parfitt, 2000). This may be due to regular interventions raising awareness of recycling, it would be interesting to analyse schemes using just communication campaigns and advisory leaflets.

There are other external factors to be considered. The reduction in economic activity since 2008 encouraging householders to behave in a more sustainable way, to waste less food, replace consumer goods less often and buy and sell second-hand items instead of disposing of 
them as waste. Manufacturers and retailers taking part in the Courtauld Commitment (WRAP, 2010) and legislation such as the Producer Responsibility Obligations (Packaging Waste) Regulations, 2007 reducing quantities of packaging waste generated within households.

\section{Conclusion}

This study has used an established time series intervention model to investigate the success of various amendments made to $\mathrm{CBC}$ household waste and recycling collection services. A crosscorrelation technique has employed to examine the interrelationship between monthly recycling and residual waste streams.

The model was able to quantify the success of the two interventions analysed (the increase in materials collected separately by $\mathrm{CBC}$ for recycling and the simplification of the collections for householders). Both showed abrupt and permanent increases in the waste collected for recycling, alongside a significant reduction in the residual waste stream. From the crosscorrelation analysis, it was concluded that interventions aimed at increasing the recycling stream would lead to an immediate (with a lag of one month) decrease in residual waste stream.

The time series model was able to predict the impact of seasons and number of working days on amounts recycled. Using updates and validation of data from WasteDataFlow it would be a useful tool to Local Authorities in devising interventions and policies associated with household waste, recycling and collection services.

\section{Acknowledgements:}

The authors would like to acknowledge the assistance and contributions of staff at Charnwood Borough Council and Serco.

\section{References:}

Barr, S., Gilg, A.W., (2005) Conceptualising and analyzing household attitudes and actions to a growing environmental problem: Development and application of a framework to guide local waste policy. Applied Geography 25 (3) 226-47.

Beigl,B., Lebersorger,S., Salhofer,S., (2008) Modelling municipal solid waste generation: A review. Waste Management 28 (3): 200-214.

Box, G.E.P., Tiao, G.C., (1975) Intervention Analysis with Applications to Economic and Environmental Problems. Journal of American Statistical Association 70 (3) 70-9.

Box, G.E.P., Jenkins G.M., (1976) Time Series Analysis: Forecasting and Control, 2nd ed. San Francisco: Holden-Day.

Box, G.E.P., Cox, D.R., (1964) An analysis of transformations (with discussion). Journal of the Royal Statistical Society, Series B, 26, 211-246.

Box G.E.P., Jenkins, G.M., Reinsel, G.C., (1994) Time series analysis: forecasting and control cliffs, 3rd ed. Englewood Cliffs, Prentice-Hall.

Burnley, S., Parfitt, J., (2000) Public attitudes to waste and waste management, UK., Dept of Environmental and Mechanical Engineering, Open University. 
Chang, N.B., Lin, Y.T., (1997) An analysis of recycling impacts on solid waste generation by time series intervention modeling. Resources, Conservation \& Recycling 19 (3)165-86.

Dahlén, L., Lagerkvist, A., (2010) Evaluation of recycling programmes in household waste collection systems. Waste Management \& Resources 28 (7) 577-86.

Department of Environment Food and Rural Affairs (Defra), 2007. Waste Strategy for England 2007. London, Defra.

Defra, Local Authority Collected Waste Management Statistics for England - Final Release for 2011/12; 2012 [online] Available at:

http://www.defra.gov.uk/statistics/files/mwb201112_statsrelease.pdf Accessed 7/1/13.

Department of Environment, Northern Ireland (DoENI). Towards Resource Management; The Northern Ireland Waste Management Strategy 2006-2020, Belfast, DoENI, 2006.

den Boer, J., den Boer, E., Jager, J., (2007) LCA-IWM: A decision support tool for sustainability assessment of waste management systems. Waste Management 27 (8) 1032-45.

Emery, A., Davies, A., Griffiths, A., Williams, K., (2007) Environmental and Economic Modelling: A Case Study of Municipal Solid Waste Management Scenarios in Wales.

Resources, Conservation and Recycling 49 (3) 244-63.

Environmental Protection Act, 1990 [online] Available at:

http://www.opsi.gov.uk/acts/acts1990/ukpga_19900043_en_1 Accessed 3/5/12.

Eriksson,O., Carlsson Reich, M., Frostell,B., Björklund,A., Assefa, G., Sundqvist, J.-O., Granath, J., Baky, A., Thyselius, L., (2005) Municipal solid waste management from a systems perspective, Journal of Cleaner Production, 13 (3) 241-252.

European Commission, 2008, revised Framework Directive (2008/98/EC) [online] Available at http://eur-

lex.europa.eu/LexUriServ/LexUriServ.do?uri=OJ:L:2008:312:0003:0030:en:PDF

Accessed 7/9/13.

Hsu, E., Kuo, C.M., (2005) Recycling rates of waste home appliances in Taiwan. Waste Management 25 (1) 53-65.

Institute of Civil Engineers (ICE), 2011. The State of the Nation; Waste and Resource Management, London, ICE.

Jenkins, R.R., Martinez, S.A., Palmer, K., Pololsky, M.J., (2003) The determinants of household recycling: a material-specific analysis of recycling program features and unit pricing. Journal of Environmental Economics \& Management, 45:294-318.

Jorquera, H., Palma, W., Tapia, J., (2000) An intervention analysis of air quality data at Santiago, Chile. Atmospheric Environment 34 (24) 4073-84. 
Local Government Association, 2007, Recycling rates rocket by $30 \%$ when councils switch to alternate weekly collection" Press release 25/4/2007. [Online] Available at: http://www.lga.gov.uk/lga/core/page.do?pageId=41797 Accessed 2/5/12.

Martin, M., Williams, I.D., Clark, M., (2006) Social, cultural and structural influences on household waste recycling: a case study. Resources, Conservation \& Recycling 48(4)357-95.

Matsuto, T., Tanaka, N., (1993) Data analysis of daily collection tonnage of residential solid waste in Japan. Waste Management and Research 11 (4) 333-43.

McLeod, F., Cherrett, T., (2008) Quantifying the transport impacts of domestic waste collection strategies. Waste Management 28 (11) 2271-8.

Muhle, S., Balsam, I., Cheeseman, C.R., (2010) Comparison of carbon emissions associated with municipal solid waste management in Germany and the UK. Resources, Conservation and Recycling 54 (11) 793-801.

Oom do Valle, P., Menezes, J., Reis, E., Rebelo, E., (2009) Reverse logistics for recycling: The customer service determinants. International Journal of Business Science \& Applied Management 4 (1) 1-17.

Producer Responsibility Obligations (Packaging Waste) Regulations, 2007 [online] Available at: http://www.legislation.gov.uk/uksi/2007/871/contents/made Accessed 7/9/13.

Read, A.D., (1999) A weekly doorstep recycling collection, I had no idea we could! Overcoming the local barriers to participation. Resources, Conservation \& Recycling 26(3)217-49.

The Scottish Government, 2010. A Zero Waste Plan for Scotland, 2010, Edinburgh, Scottish Government.

Tucker, P., Grayson, J., Spiers, D., (2001) Integrated effects of a reduction in collection frequency for a kerbside newspaper recycling scheme. Resources Conservation \& Recycling 31 (2) 149-70.

WasteDataFlow. [Online] Available at: http://www.wastedataflow.co.uk/2007 Accessed $18 / 3 / 13$.

Watson, M., Bulkeley, H., 2005. Just Waste? Municipal Waste Management and the Politics of Environmental Justice. Local Environment 10(4):411-26.

Welsh Assembly Government. 2010. Towards Zero Waste, One Wales: One Planet, Cardiff, Welsh Assembly Government.

Wilson, C.D.H., Williams, I.D., (2007) Kerbside collection: A case study from the northwest of England. Resources, Conservation \& Recycling 52 (2) 381-94.

Woodward, R., Bench, M., Harder, M.K., (2005) The Development of a UK Kerbside Scheme Using Known Practice. Journal of Environmental Management, 75 (2) 115-27. 
WRAP, 2009, Analysis of Kerbside Dry Recycling Performance in England 2007/08, Oxon, WRAP.

WRAP, Case studies, Courtauld Commitment Phase 1 (2005-2010), Oxon, WRAP [online] Available at:

http://www.wrap.org.uk/sites/files/wrap/CC\%20Case\%Studies\%2\%2019\%20Aug\%202010\% 20final.pdf2010. Accessed 3/9/13. 